\title{
Have IFRS Positive Impact on the Regulatory Accounting Systems in Continental European Countries?"
}

\author{
Marcela ŽÁROVÁ* - Ladislav MEJZLÍK * $^{* *}$
}

\section{Introduction}

It is said that IFRS brings positive - impact on the quality of local accounting rules. Within each country, local regulations govern, to a greater or lesser degree, the issue of financial statements. Such local regulations include accounting standards which are promulgated by the regulatory bodies and/or the professional accounting bodies in the countries concerned. ${ }^{1}$

This article investigates statement that IFRS have positive impact on the regulatory system in continental European countries. Continental European countries are represented by the Czech Republic for this purpose of investigation. The article dealt with regulatory accounting system in the Czech Republic, where local regulations include accounting standards only by names, but not as an output of regular due process and which are not issued by the professional accounting body at all, not even partially. As the characteristic features of the Czech regulatory system are observable in other continental European countries too, conclusion from this research is applicable to a wide range of European countries. Czech Republic belongs to the codified Roman law system. Characteristic

\# This paper was prepared in the framework of research plan Development of Accounting and Financial Theory and its Application in Practice from Interdisciplinary Point of View (registered number MSM 6138439903).

Doc. Ing. Marcela Žárová, CSc. - Associate professor; Department of Financial Accounting and Auditing, Faculty of Finance and Accounting, University of Economics, Prague, W. Churchill Sq. 4, 13067 Prague 3, Czech Republic; <zarova@ vse.cz>.

** Doc. Ing. Ladislav Mejzlík, PhD. - Associate professor; Department of Financial Accounting and Auditing, Faculty of Finance and Accounting, University of Economics, Prague, W. Churchill Sq. 4, 13067 Prague 3, Czech Republic; <lmejzlik@vse.cz>.

1 International Financial Reporting Standards: Preface to Statements of International Accounting Standards; part Accounting Standards (art.8), 2009 International Accounting Standards Committee Foundation (IASCF) (IASB, 2009). 
features of the accounting regulatory system in continental European countries that are developed in this law environment, is that law specifies the rules in a great detail (Žárová, 2006). This seems to be the greatest disadvantage of such regulatory system. At first, legislators never give priority to laws concerning financial reporting and therefore laws are often enacted after considerable delays by the time they come into force and they are nearly out of date. Law does not seem to be effective way of dealing with urgent problems or with new topics or development in financial reporting. Financial reporting regulated by law is too detailed on one hand and on the other hand most legislators are not well informed about accounting concepts and technicalities of financial reporting. There is a danger that provisions of the law will be inappropriate. At second the stock exchange is less important, companies obtain majority of their funds from banks and other financial institutions. Naturally this regulatory system of accounting, the system where the Accounting Act is on the top of the regulatory hierarchy, is supplemented and completed by a number of other rules, in the case of the Czech Republic, issued by the same institution of the government that provides the Act. The natural consequence of these facts is that financial statements play a less important role in providing information for investors, as providers of debt finance and venture capital are generally able to obtain all information that they need through direct contacts with the company's management.

The regulation of the financial accounting and reporting in the Czech Republic, in the early nineties, has been developed under the above said circumstances, where a tax orientation of accounting existed. At the beginning of nineties of the last century external reporting has been largely invented for the purpose tax base determination. In such circumstances, there may be little motivation for companies to publish financial information. The government has to intervene to oblige companies to do so. The form of such intervene in the hands of the government was the law only. Another characteristic feature of the accounting regulatory system is its connection to the tax rules. Rules used to compute taxable profit were introduced directly into the accounting rules in order to simplified consequent process of revising accounting data by financial authorities.

The first Accounting $\mathrm{Act}^{2}$ (hereafter the Act) was approved by the Czech Parliament in 1991, commencing the process of transition from a

\footnotetext{
2 Accounting Act No 563/1991 Coll. as amended by Act No 495/2005 Col.
} 
centrally planned economy to a market economy. In May, 2004, the Czech Republic joined the European Union (EU). Becoming a member of the EU has been crucial to speeding up reform of the Czech accounting system (Žárová, 2008). As a member, the Czech Republic is committed to requiring its listed companies to comply with international financial reporting standards in their consolidated financial statements at least. The Czech accounting system demonstrates the consequences of the European Commission's decision to apply the IAS/IFRS at the national level. But what stayed unclear was how to deal with the July 2002 Regulation of the European Union on the application of IFRS and to what extent this requirement will be extended to other companies.

Accounting practices were reformed to ensure that new laws were consistent with those of the European Community (EC), so as to facilitate transition to full membership. New legislation was therefore influenced by EC accounting practices and IFRS since 2005 .

\section{Steps of implementation of IFRS into the Czech accounting system and impact of IFRS on accounting system}

First regulatory rules for accounting as for financial reporting in EC were issued in 1978 - EC 4th Directive. Requirements set out in Directives regulated accounting issued in the period started in 1978 till 1991, couldn't ensure comparability of financial reporting in publicly traded Community companies and the high level of transparency of accounting information, there was a requirement to apply a single set of high quality international accounting standards for the preparation of their financial statements. In 2000, the Commission published its Communication on "EU Financial Reporting Strategy: the way forward" in which it was proposed that all publicly traded Community companies prepare their consolidated financial statements in accordance with one single set of accounting standards, namely International Accounting Standards (IAS), at the latest by the year 2005. In the Communication, there were mentioned consolidated financial statements only. In the proposed Regulation on the application of IAS, Member States had an option to permit or require publicly traded companies to prepare annual accounts in conformity with adopted international accounting standards. Regulatory rules were approved by the European parliament as Regulation (EC) No 1606/2002 of the European Parliament and of the Council of 19 July 2002 on the application of international accounting standards. 
A new phenomenon appears in accounting rules in the Czech Republic. From the historical overview it is known that the accounting regulatory body - Ministry of Finance in the Czech Republic changed from year to year procedures concerning rules according those accounting units were allowed to prepare financial statements in compliance with IFRS. Here is an overview of main facts:

In the period covering 1991-2002, "In addition to financial statements prepared in compliance with the Act on Accounting, accounting units may also provide accounting information those are prepared in compliance with IFRS or other internationally recognized accounting principles."

In the period covering the year 2003, there was no change in using IAS from previous amendment of the Act on Accounting and accounting units were allowed to use besides domestic rules IAS or other internationally recognized accounting principles.

In the period starting in the year 2004 till present, there was substantial change in using and implementation of IFRS. The year 2004 became crucial historical moment in the existence of the Czech Republic, also in accounting regulation. In May, 2004, the Czech Republic joined the European Union (EU). Adoption of the 2002 EU Regulation on the application of IFRS had fundamental effects on further development of accounting rules in the Czech Republic. Since joining the EU all listed companies shall prepare at least their consolidated financial statements in accordance with IASC standards by 2005 at the latest. The Accounting act dealing systematically with obligation to use of IFRS was issued firstly in the year 2004 .

How this regulation was realized in the Czech accounting system? Answer on this question seems to be easy enough as there is no doubt about proper answer. Where is then the point to be discussed? The stumbling block is in "companies shall prepare their consolidated accounts in conformity with the international accounting standards". Statutory text of Regulation (EC) No 1606/2002 was to prepare financial statements in conformity with the international accounting standards. Implementation of article 4 of EC Regulation into Act on Accounting in the Czech Republic has completely different impact. The Act was amended by a new article again in the section 19 called "Balance sheet day", subsection 9. Accepted text of the law in the year 2002 was: "In 
addition to financial statements prepared in compliance with the Act on Accounting, accounting units may also provide accounting information those are prepared in compliance with IFRS or other internationally recognized accounting principles."

Following text replaced subsection 9 as of 1 May 2004, at the date of the Czech Republic's accession to the European Union. The replaced subsection 9 stated: "Accounting units (accounting entities) which are business companies issuing securities listed on a regulated market of securities (i.e. are publicly- traded companies) in the European Union's Member States shall apply international accounting standards as governed by the European Community's law to keeping their accounts and preparing their financial statements. For the purpose of this Act, "regulated market in the Czech Republic" shall mean a public market pursuant to another Act."

The only regulator of accounting in the Czech Republic, the Ministry of Finance, Department of accounting, made either very fundamental mistake in translation and understanding of "prepare their consolidated accounts" or intention of the regulatory body to include additional obligation to companies in very sophisticated way into the law. Exact wording of the law (Accounting Act No 563/1991 Coll. as amended by Act No 437/2003 Col.) is not only to meet obligation of companies to prepare consolidated accounts in conformity with the international accounting standards but also to keep their accounts.

There is no additional obligation of companies as for keeping their account in compliance with IFRS in Regulation (EC) No 1606/2002. ${ }^{3}$ There is the point of decision making for regulators of accounting in Member States that concerns option in respect of annual accounts and of non-traded companies. Exact wording of this point is in Article 5, as followed:

\footnotetext{
${ }^{3}$ Regulation (EC) No 1606/2002 of the European Parliament and of the Council of 19 July 2002 on the application of international accounting standards. [on-line], Brussels, EC Commission, c2002, [cit. 23 ${ }^{\text {rd }}$ March, 2009], $<$ http://eur-lex.europa.eu/LexUriServ/LexUriServ.do?uri=CELEX:02002R160620080410:EN:NOT>.
} 


\section{Article $5^{4}$}

Options in respect of annual accounts and of non publicly-traded companies

Member States may permit or require:

a) the companies referred to in Article 4 to prepare their annual accounts,

b) companies other than those referred to in Article 4 to prepare their consolidated accounts and/or their annual accounts,

in conformity with the international accounting standards adopted in accordance with the procedure laid down in Article 6(2).

Conclusion is that Czech companies not only "prepare financial statement in conformity with the international accounting standards but also keeping their accounts in conformity with the international accounting standards. On the other hand enlargement of original statutory text in Article 4 of Regulation (EC) No 1606/2002 in exact wording "prepare their consolidated accounts in conformity with the international accounting standards" by another obligation of keeping their accounts in conformity with the international accounting standards could be contrivance of the Ministry of Finance in the Czech Republic."

In conformity with IAS adopted in Regulation (EC) No 1606/2002 on the application of international accounting standards since 2004 using of IFRS in the Czech Republic is obligatory for:

- consolidated accounts of publicly traded companies

- annual accounts of publicly traded companies

(if their securities are admitted to trading on an EC regulated market)

Above stated companies not only prepare their financial statements in compliance with IFRS but also keeping their accounts in conformity with the international accounting standards.

\footnotetext{
4 Article 5 of the "Regulation (EC) No 1606/2002 of the European Parliament and of the Council of 19 July 2002 on the application of international accounting standards"
} 
Those companies which has obligation to prepare financial statement in compliance with IFRS has obligation to keep their accounts in compliance with IFRS as well as. IFRS substitute domestic rules completely. Companies either use IFRS or Czech rules for keeping their accounts and for reporting in financial statements.

The Czech enterprises having to apply the IFRS there are many voices raised because of the difficulties in keeping literal transcription of the law as for keeping their accounts in conformity with the international accounting standards. Among these difficulties there can be stated:

- Incomparability of accounting data in time series

- Incomparability of reported data in groups

- Impact on enterprise information systems

- Impact on requalification of the accounting staff

- Impact on strategic management of companies

- Discontinuity of accounting policies (distribution of profit, motivations systems etc.)

- Existence of organizational problems in bookkeeping systems of companies (financial statements translation in groups, accounting for tax purposes etc.)

- Lack of understanding of IFRS principles in profession

Impact of the introducing IFRS on the Czech accounting regulatory system is described in the figure 1:

Fig. 1: Impact of IFRS on the Czech accounting regulatory system

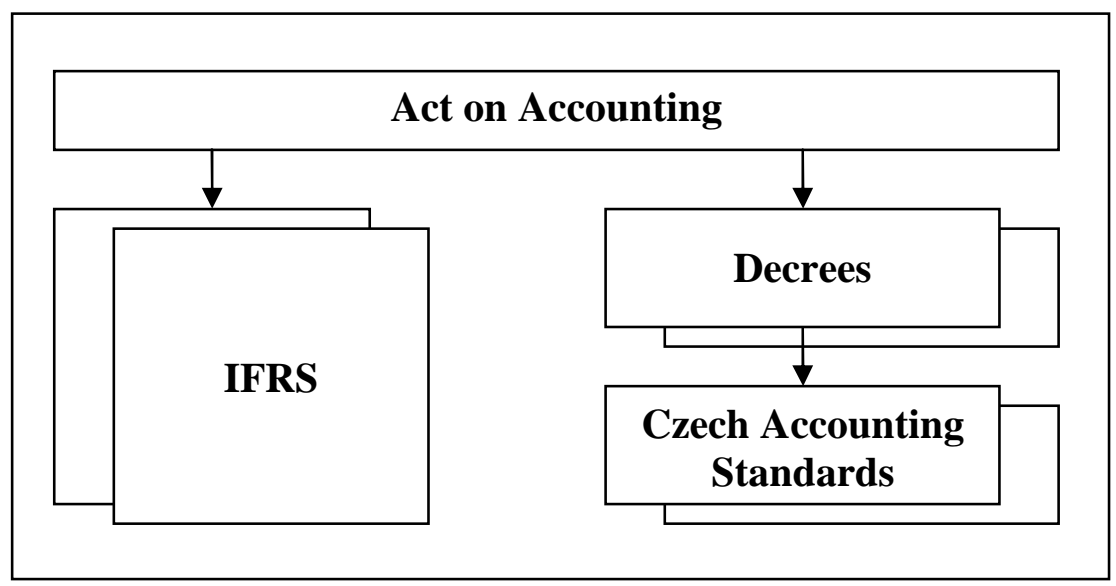


Figure 1 clearly demonstrates that those companies which has obligation to prepare financial statement in compliance with IFRS has obligation to keep their accounts in compliance with IFRS as well. IFRS substitute domestic rules completely. The hierarchy of domestic rules consists of Act on Accounting, Decrees ${ }^{5}$, Czech Accounting Standards ${ }^{6}$. Companies either use IFRS or Czech rules for keeping their accounts and for reporting in financial statements.

Figure 2 illustrates three groups of accounting entities existing in the accounting system. Respecting legal and organizational aspect of division accounting entities, there are existing groups from companies to sole traders according to used rules in the Czech accounting system.

Group No. 1 covers large companies listed on capital market, their financial statements are audited. This group is obliged to use IFRS for keeping accounts and preparing financial statements. Accounting entities belonging into group No. 2 keeping their accounts and prepare financial statements in compliance with Czech accounting standards. This group of accounting entities covers audited accounting entities as well as entities those haven't requirement to be audited. Entities in this group are not allowed to use IFRS either for keeping accounts or preparing financial statements. Group No. 3 covers small companies and sole traders. Even if the accounting entity is a company, these companies declared as small companies has not obligation to be audited and they are not allowed to use Czech accounting standards. They must keep accounts and prepare their financial statements in compliance with simplified double entry bookkeeping. Sole traders prepare cash based- bookkeeping primarily for the tax purposes.

This division of accounting entities in the Czech Republic is rigid. Meaning of this statement is that there is strictly stated in the Act, Decrees and Czech accounting standards obligations of different group of accounting entities and there is also stated which set of rules are compulsory and on the other hand which are prohibited to be used.

\footnotetext{
5 Decree on Accounting for Business No 500/2002 Col. as amended by Decree No. 472/2003Col., 397/2005 Col., 349/2007 Col. And 469/2008 Col.

${ }^{6}$ Czech Accounting Standards 1-23 in effect as of January 1, 2009, issued by the Ministry of Finance in compliance with article 36 of Accounting Act No 563/1991 Coll. as amended by Act No 495/2005 Col.
} 
Fig. 2: Division of companies and sole traders according to the used rules in the accounting system

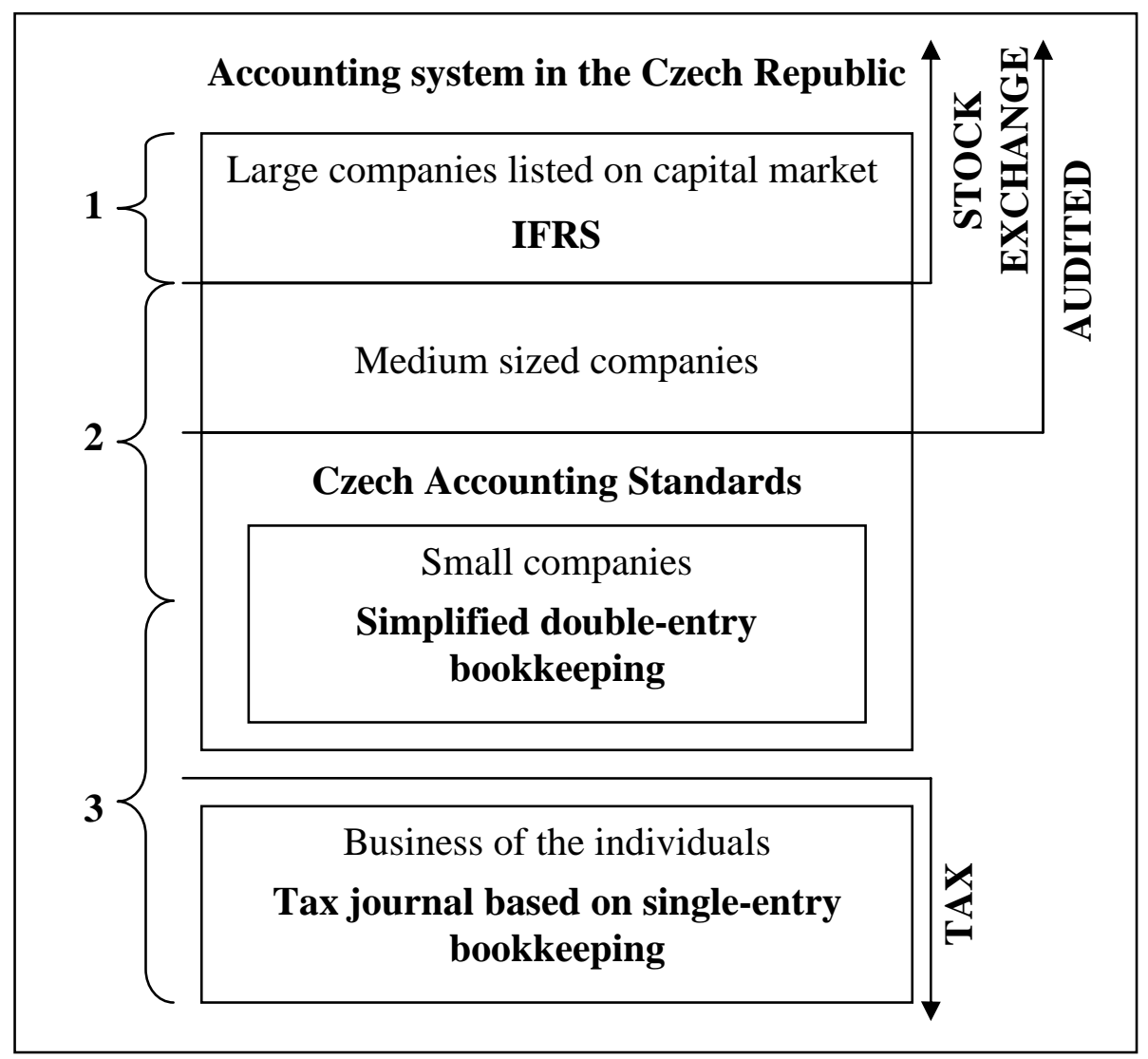

Accounting profession in the Czech Republic and the role in the process of IFRS implementation

Accounting profession has traditionally no role in the Czech Republic. This fact is a natural consequence of the development of accounting regulatory system, where the most important factor, standing above the others, is the legal system. As arises from the historical overview, the only regulatory body of accounting in the Czech Republic is the Ministry of Finance. Accounting is regulated by the Act prepared by the Ministry of Finance and approved by the Parliament. The Ministry of Finance issued also detailed regulatory guidance for accounting which consisted of an obligatory chart of accounts and accounting procedures in the period of 1990-2002. Even though Regulatory guidance for accounting was not 
part of the Act, it became obligatory as it was strictly required by tax authorities. Later, regulatory guidance for accounting was replaced by degree and standards, but both instruments were issued and approved by the Ministry of Finance.

Czech accounting standards are an integral part of the three levels of accounting regulation. Standards are issued by the Ministry of Finance. Standards are issued separately for different accounting entities and determine admissible accounting method or procedures. They are not developed under due process, where organizations or individuals submit their suggestions.

The first standard setter is the Ministry of Finance, the only regulator of the accounting in the Czech Republic and the second one, the potential one, could be any legal entity selected in public tender as a standard setter, that suppose to be a professional independent rule-making body. The most important fact in the due process is that governmental agency Ministry of Finance develops standards without opening process of comment by public, without respecting due process. Comments on draft of standard are usually the matter of other governmental institutions only. Exposure draft is not published and accessible for public comments at all.

Rigidity of the accounting regulatory system, the lack of the substantial body of private shareholders means that the need for auditors and certified accountants is much smaller than it is in UK or USA. Accounting profession has no tradition in the Czech Republic in contrary with the tradition of tax experts. Only in late nineties of the last century the Chamber of Auditors was established in the Czech Republic. This professional body set exams, consider ethical matters, belongs to the international accounting bodies and so on. The existing accountancy body has taken over a regulatory role for audit, under the supervision of the government.

\section{National Accounting Board}

Strengthening influence of IASB in Europe and impact of IFRS, that became the only rules for preparing consolidated financial statement for listed companies on European stock markets and their implementation into such systems where traditionally no standards as the best practise of accounting professionals exists, caused a new possible role for accounting profession. In 2001 an independent national accounting body - the Czech 
National Accounting Board - was established. Board was established by the initiative of Czech accountants, the Chamber of Auditors, Faculty of Finance and Accounting at the University of Economics in Prague, and the Chamber of Tax Advisors. At the beginning of their existence, the main aim of this body is to support the development of accountancy toward an independent respected profession in the Czech Republic, to establish a chamber of accountants, and to participate in the process of issuing national accounting standards developed through a formal system of due process.

At the same time, when Regulation (EC) No 1606/2002 on the application of international accounting standards with requirement for the use IFRS since 2005, there is an interesting appearance in the Czech accounting. There is a definite endeavour of the Ministry of Finance to implement some of the best practise of accounting professionals, worldwide respected, into the Czech accounting standards. This endeavour brings sometime very complicated situations and causes breakdown of the accounting system. Some methods, measurements or rules, used in IFRS, are implemented into the national accounting system partially, incompletely or even without the knowledge of the far-reaching consequences. Ignorance of far-reaching consequences of accounting rules brings every year companies to courts, to higher costs and to loose confidence by users of accounting information. The poor quality of the Czech accounting standards leads, in many cases, to their breaking. Accounting entities, especially those owned by foreign companies or those reporting to parent companies, treat their transactions in compliance with fair regulations even if this treatment breaks Czech law for accounting. Consequence of this practice is that rules are used differently for treatment of the same cases. This brings complications to audit and preparers of financial statement as well. Auditors, preparers of financial statement and users too, often doubt whether to prefer substance of the transaction or legal consequence of the transaction.

The National Accounting Board prepared a list of most urgent issues in the Czech accounting:

1. The concept substance over form is not respected in the Czech accounting; consequence of the absence of this concept is that leased assets are not reported in the balance sheet of the lessee as well as the long-term lease obligation. 
2. Some categories of intangible assets recognized in compliance with the Czech accounting standards differ from IFRS e.g. formation costs. The Czech accounting standards don't have clear criteria for distinction between research and development.

3. Rule for situation where entities depreciate separately some parts of an item of property, plant and equipment is not known in the Czech accounting standards.

4. The Czech accounting standards have different criteria for recognition of provision. Example of the title to create provision in the Czech accounting is repair and maintenance of long-lived assets.

5. There is not exact definition of assets, liabilities, revenue, expense, gain and losses. Revenue recognition principle differs from the one in IFRS.

6. Revenue, expense, gain and losses are not recognized separately in the income statement. No separate line exists for above mentioned categories.

7. Income statement is prepared with classification of cost production method in majority of cases. Revenues are influenced by items "changes in inventories of finished goods and work in progress" that doesn't meet criteria for revenue.

8. Extraordinary items are separately recognized in the income statement.

9. There is no rule in the Czech accounting standards for discontinued operations and concept for assets held for sale, as in IFRS 5 , in order to ensure consistency and comparability of financial statements.

10. Even in a group, where there are companies those are issuers of a security and issuer of bonds and companies those are not issuers, they have obligation to prepare their financial statements according to separate accounting rules. Czech accounting rules and IFRS differs, as described above, from many essential aspects. This is a fundamental complication for consolidation and the quality of accounting information.

Solving above mentioned most urgent issues, the National Accounting Board could bring about convergence of national accounting standards and IFRS to high quality. This could be realized, we suppose, only under the conditions described in Scenario 3 described bellow. 
As has already been noted, the fact that some of IFRS practice, rules and measurement were implemented, mostly incompletely, into the Czech accounting standards, leads the Czech National Accounting Board to decision to issue interpretations of the Czech accounting standards. Interpretations would provide timely guidance on financial reporting issues not specifically addressed in the Czech accounting standards, issues differently treated in compliance with Act on Accounting and the Czech accounting standards or issues that lead to different treatment. Selected topics of interpretations: Temporary differences in initial recognition of assets; Temporary differences in combination; Income tax provision; Deferred taxes on temporary differences arising from equity method measurement; First recognition of deferred taxes; Factoring; Comparability of accounting information in subsequent years; Accounting for responsibilities as for quality of service; Accounting for grant and governmental assistance and the others.

\section{Impact of IFRS on architecture of the accounting regulatory system}

To realised convergence of the Czech accounting standards and IFRS to high quality solutions, there should be strength the position, role and impact of the accounting profession in the regulatory accounting system in order to develop national accounting standards through a formal system of due process.

Solving above mentioned most urgent issues, the National Accounting Board could bring about convergence of national accounting standards and IFRS to high quality. The main obstacle for solving the most urgent issues in Czech accounting is the fact that this could be realized only under the conditions described in Scenario 3 bellow. In other cases, we are rather sceptical about correct solution of this issue. Rather pessimistic conclusion originate from the fact that the Ministry of Finance doesn't respect accounting practice and rarely are able to follow the latest development of worldwide development of accounting, especially IFRS. This seems to be the greatest obstacle and disadvantage of regulatory system developed under the influence of the codified Roman law system. And the last but not the smallest obstacle that has to be taken into consideration, describing the process of construction of the accounting system, is a strong influence of taxes. 
We have prepared three scenarios based on a study of direct influences such as law system, position of accounting profession, present construction of accounting regulatory system, convergence of national accounting standards and IFRS to high quality and accounting environment in the Czech Republic.

\section{Scenario No. 1}

Scenario No. 1 assumes that in all three level of accounting there exist rules, where rule-making body is the Ministry of Finance. Legal Act is approved by the Government, decrees and Czech Accounting standards are approved by the Ministry of Finance. Position of the professional accountants is rather poor with very low influence on standards settings. This scenario describes present situation in the Czech Republic. Tab. 1 below represents present situation.

Tab. 1: Scenario No. 1

\begin{tabular}{|l|l|l|}
\hline \multicolumn{3}{|c|}{ Three-level accounting regulation system } \\
\hline $\begin{array}{l}\text { 1. Legal Act: } \\
\text { Accounting Act }\end{array}$ & $\begin{array}{l}\text { Rule-making body: } \\
\text { Ministry of Finance }\end{array}$ & $\begin{array}{l}\text { Approved by: } \\
\text { Government/Parliament }\end{array}$ \\
\hline 2. Decrees & $\begin{array}{l}\text { Rule-making body: } \\
\text { Ministry of Finance }\end{array}$ & $\begin{array}{l}\text { Approved by: } \\
\text { Ministry of Finance }\end{array}$ \\
\hline $\begin{array}{l}\text { 3. Standards } \\
\text { Czech Accounting } \\
\text { Standards }\end{array}$ & $\begin{array}{l}\text { Rule-making body: } \\
\text { Ministry of Finance } \\
\text { OR any legal entity } \\
\text { selected in public } \\
\text { tender as a standard } \\
\text { setter }\end{array}$ & $\begin{array}{l}\text { Ministry of Finance even } \\
\text { if rule-making body } \\
\text { differs from MF }\end{array}$ \\
\hline
\end{tabular}

This scenario includes possibility that has never come into truth: Czech accounting standards may be developed by any legal entity selected in public tender as a standard setter. Only the Ministry of Finance develops and approves Czech accounting standards. The reason is that public tender is announced by the Ministry of Finance. 


\section{Scenario No. 2}

Scenario No. 2 assumes that in two level of accounting there exist rules, where rule-making body is the Ministry of Finance. Legal Act is approved by the Government; decrees are approved by the Ministry of Finance. The Ministry of Finance announces public tender to select an author of Czech Accounting standards. Complication can be caused in the situation when the Ministry of Finance announces public tender only for selected titles of accounting standards. Position of the professional accountants is starts to strength with influence on standards settings but only as for those standards developed through a formal system of due process. This scenario describes hypothetical situation in the Czech Republic. Existence of asymmetry in division of responsibilities between governmental institutions and professional rule-making body causes hybrid accounting system (Žárová, 2007). While a standard developed by a professional rule-making body is consistently verified by public professionals, a standard developed by a governmental institution is not accessible for public verification at all, because there is a different regime of due process.

Tab. 2: Scenario No. 2

\begin{tabular}{|l|l|l|}
\hline \multicolumn{3}{|c|}{ Three-level accounting regulation system } \\
\hline $\begin{array}{l}\text { 1. Legal Act: } \\
\text { Accounting Act }\end{array}$ & $\begin{array}{l}\text { Rule-making body: } \\
\text { Ministry of Finance }\end{array}$ & $\begin{array}{l}\text { Approved by: } \\
\text { Government/Parliament }\end{array}$ \\
\hline 2. Decrees & $\begin{array}{l}\text { Rule-making body: } \\
\text { Ministry of Finance }\end{array}$ & $\begin{array}{l}\text { Approved by: } \\
\text { Ministry of Finance }\end{array}$ \\
\hline $\begin{array}{l}\text { 3. Standards } \\
\text { Czech Accounting } \\
\text { Standards }\end{array}$ & $\begin{array}{l}\text { Rule-making body: } \\
\text { Ministry of Finance } \\
\text { OR any legal entity } \\
\text { selected in public } \\
\text { tender as a standard } \\
\text { setter }\end{array}$ & $\begin{array}{l}\text { Ministry of Finance } \\
\text { OR public professionals }\end{array}$ \\
\hline
\end{tabular}

Existence of hybrid regulatory accounting system brings several issues to be solved:

Who is responsible for division of topics treated between Ministry of Finance and by professional independent standard setter? 
1. Comparability of development of standards and standards due process realized by the Ministry of Finance and by professional independent standard setter

2. Asymmetry in verification of usefulness of draft treatment by public.

3. Payment of costs incurred in the process of standard development.

A key feature of introduction of national accounting standards into rigidly regulated environment is existence of hybrid regulatory system. Hybrid regulatory system appears in those regulatory accounting systems where two different standards setting bodies exist. This is an example of the German regulatory accounting system, where two standard setting bodies exist in the regulatory system: Ministry of Justice and German Accounting standards Board (DSR) (Schmidt - Kirchner, 2005). Similar development of the hybrid regulatory accounting system will may to be expected in the Czech Republic. Starting point for development of hybrid regulatory accounting system has already been realized by introduction of Czech Accounting Standards development by any legal entity selected in public tender. This fact becomes part of the Act on Accounting when National Accounting Standards were introduced by the legislator into the Act on Accounting and came into force since 2004. The article of the Act determines Ministry of Finance or any legal entity selected in public tender as a standard setter. This is historically the first moment when Ministry of Finance in the Czech Republic admits the possibility of existence a rule-making body that differs from Ministry of Finance. Existence of the rule-making body that differs from Ministry of Finance opens the possibility to develop hybrid regulatory accounting system.

\section{Scenario No. 3}

Scenario No. 3 assumes that in two level of accounting there exist rules, where rule-making body is the Ministry of Finance. Legal Act is approved by the Government; decrees are approved by the Ministry of Finance. As for standard setting process there could be two steps. In the step No.1, the Ministry of Finance announces public tender to select an author of Czech Accounting standards. In the step No.2, professional accounting body, represents by the National Accounting Board develop standards through a formal system of due process. This scenario will fully respect the position of the accounting profession and will lead towards convergence of national accounting standards and IFRS to high quality. 
Tab. 3: Scenario No. 3

\begin{tabular}{|l|l|l|}
\hline \multicolumn{3}{|c|}{ Three-level accounting regulation system } \\
\hline $\begin{array}{l}\text { 1. Legal Act: } \\
\text { Accounting Act }\end{array}$ & $\begin{array}{l}\text { Rule-making body: } \\
\text { Ministry of Finance }\end{array}$ & $\begin{array}{l}\text { Approved by: } \\
\text { Government/Parliament }\end{array}$ \\
\hline 2. Decrees & $\begin{array}{l}\text { Rule-making body: } \\
\text { Ministry of Finance }\end{array}$ & $\begin{array}{l}\text { Approved by: } \\
\text { Ministry of Finance }\end{array}$ \\
\hline $\begin{array}{l}\text { 3. Standards } \\
\text { Czech Accounting } \\
\text { Standards }\end{array}$ & $\begin{array}{l}\text { Rule-making body: } \\
\text { Accounting } \\
\text { professionals - } \\
\text { National Accounting } \\
\text { Board }\end{array}$ & Public professionals \\
\hline
\end{tabular}

\section{Conclusion}

Impact of IFRS on the regulatory systems has different stress in different European countries. Impact of IFRS has very special consequences in accounting regulatory system in the Czech Republic, where the only regulatory body of accounting is the Ministry of Finance. Interpretation of "Regulation (EC) No 1606/2002 of the European Parliament and of the Council of 19 July 2002 on the application of international accounting standards" that introduced the Ministry of Finance into the Act on Accounting had fundamental impact on used accounting rules in the Czech Republic and on the architecture of the Czech accounting regulatory system too. Article brings critical review of rigidly understanding of rules for preparing of financial statements and keeping accounts. Meaning of this statement is that there is strictly stated in the Act, Decrees and Czech accounting standards obligations of different group of accounting entities which set of rules are compulsory and on the other hand which are prohibited to be used. This statement is under the criticism in the article.

This division of accounting entities in the Czech Republic is rigid. Meaning of this statement is that there is strictly stated in the Act, Decrees and Czech accounting standards obligations of different group of accounting entities and there is also stated which set of rules are compulsory and on the other hand which are prohibited to be used. 
Introduction of IFRS that was realized in the Czech accounting only partially, brings sometime very complicated situations and causes breakdown of the accounting system. Some methods, measurements or rules, used in IFRS, are implemented into the national accounting system partially, incompletely or even without the knowledge of the far-reaching consequences. Ignorance of far-reaching consequences of accounting rules brings every year companies to courts, to higher costs and to loose confidence by users of accounting information. The poor quality of the Czech accounting standards leads, in many cases, to their breaking. Accounting entities, especially those owned by foreign companies or reported to parent companies, treat their transactions in compliance with fair regulations even if this treatment breaks Czech law for accounting. Consequence of this practice is that rules are used differently for treatment of the same cases. This brings complications to audit. Auditors, preparers of financial statement and users too, often doubt whether to prefer substance of the transaction or legal consequence of the transaction.

This serious situation leads to incomparability of accounting data in time series, incomparability of reported data in groups, impact on enterprise information systems, impact on requalification of the accounting staff, impact on strategic management of companies, mostly discontinuity in using accounting policies (distribution of profit, motivations systems etc.) sometimes there are organizational problems in bookkeeping systems of companies (financial statements translation in groups, accounting for tax purposes etc.) and one of last points could be lack of understanding of IFRS principles in profession.

We have prepared three scenarios based on a study of direct influences such as law system, position of accounting profession, present construction of accounting regulatory system in the Czech Republic with the aim of convergence of national accounting standards and IFRS to high quality solutions.

Our findings are that IFRS might have positive impact on the regulatory accounting system only on condition that there is a strong position of the accounting profession. There should be strength the position, role and impact of the accounting profession in the regulatory accounting system in order to develop national accounting standards through a formal system of due process. We encourage the National Accounting Board to continue its efforts to remove strictly stated obligations which set of rules are 
compulsory and on the other hand which are prohibited to be used. We encourage the National Accounting Board to represent accounting profession and became the only standard setter in the Czech Republic. Any other scenario wouldn't bring positive impact of IFRS on regulatory accounting system.

\section{References}

[1] IASB (2009): International Financial Reporting Standards 2007. London, International Accounting Standards Board, 2009.

[2] Schmidt, M. - Kirchner C. (2005): Private Law-Making: IFRS Problems of Hybrid Standard Setting. In: Nobel, P. (ed.): International Standards and the Law. Berne, Stämpfli, pp. 67-82.

[3] Žárová, M. (2006): Regulace evropského účetnictví. Praha, Oeconomica, 2006.

[4] Žárová, M. (2007): Analysis of Hybrid Regulatory Accounting Systems. European Financial and Accounting Journal, 2007, vol. 2, no. 1 , pp. 8-25.

[5] Žárová, M. (2008): Accounting Reform in the Czech Republic. In: McGee, R. W. (ed.): Accounting Reform in Transition and Developing Economies. Miami, Springer, 2008, pp. 89-100. 


\title{
Have IFRS Positive Impact on the Regulatory Accounting Systems in Continental European Countries?
}

\author{
Marcela ŽÁROVÁ - Ladislav MEJZLÍK
}

\begin{abstract}
This article investigates statement that IFRS have positive impact on the regulatory system in continental European countries. The accounting regulatory system is used for the purpose of investigation. Authors of the paper developed theoretical scenarios of potential development of the accounting system in the Czech Republic. Rigid architecture of the accounting system, rigid set of accounting rules with no tradition of accounting profession, were considered in the development of potential accounting systems in the Czech Republic. Steps of IFRS implementation are monitored and partial implementation of IFRS into Czech accounting standards are under the criticism of the authors. There is a definite endeavour of the Ministry of Finance to implement some of the best practise of accounting professionals, worldwide respected, into the Czech accounting standards. This endeavour brings sometime very complicated situations and causes breakdown of the accounting system. The paper emphasizes on the most urgent issues. The study provides clear evidence under which conditions, in the system with continental European law, could the national accounting standards be developed through a formal system of due process. It can therefore be assumed that the impact of IFRS on accounting regulatory system in other continental European countries is similar.
\end{abstract}

Key words: Regulatory systems; IFRS; Due process.

JEL classification: M41. 